\title{
Physical, Chemical and Microbiology Characteristics of Kinang Extract Powder with Maceration Extraction Method
}

Wida Priyanka Savira ${ }^{1}$, Agus Wijaya ${ }^{2}$, Rindit Pambayun ${ }^{3 *}$

${ }^{1}$ Agroindustrial Technology Interest on Agribusiness Magister Program, Faculty of Agriculture, Sriwijaya University, Indonesia

${ }^{2}$ Department of Agricultural Technology, Faculty of Agriculture, Sriwijaya University, Jl. Palembang-Prabumulih Km 32, Ogan Ilir 30139, Indonesia

DOI: $10.36347 /$ sjet.2020.v08i01.004

| Received: 02.01.2020 | Accepted: 11.01.2020 | Published: 25.01.2020

*Corresponding author: Rindit Pambayun

E-mail: rpambayun@yahoo.com

\section{Abstract}

Original Research Article

The objective of the research was to determine chemical and antimicrobial characteristics of kinang extract powder produced with maceration method. The study used a factorial randomized block design. Two factors were investigated, namely maceration time (24, 48 and 72 hours) and sieve size (60, 80 and 100 mesh). All experiment was conducted in triplicates. The following parameters were observed, including chemical (antioxidant activity, total phenol, moisture content and bulk density) and microbial (antibacterial activity). The result showed that maceration time had significant effects on antioxidant activity, total phenol, antibacterial activity, moisture content and bulk density, whereas sieve size significantly affected moisture content and bulk density. Moreover, interaction of the two factors had significant effects on antibacterial activity and bulk density.

Keywords: Powder, kinang extract, extraction, maceration.

Copyright @ 2020: This is an open-access article distributed under the terms of the Creative Commons Attribution license which permits unrestricted use, distribution, and reproduction in any medium for non-commercial use (NonCommercial, or CC-BY-NC) provided the original author and source are credited.

\section{INTRODUCTION}

Tradition and culture show the identity of a nation, such as questioning in Indonesia with the diversity of tribes that show diverse traditions as well. Menginang or commonly known as betel chewed is one of the traditions of the Indonesian people and has been known since the 6th century AD [1]. Menginang is the process of masticating the host material consisting of betel leaves, betel nuts, lime (past aqueous calcium hydroxide), tobacco and gambier which in the mouth will be accumulated by saliva so that it changes the reddish color of the teeth [2].

Nginang is a term for chewing betel in Javanese that requires other ingredients as ingredients. Equipment for preparing betel chewed generally consists of betel leaves, areca nut, lime (wet/raw or dry), gambier, and tobacco. Some add cardamom to this herb. All the ingredients are then wrapped in betel leaves. Tobacco is usually used at the end after finishing chewing the kinang. In other areas, some stay without consuming tobacco. Equipment for preparing kinang or also commonly called betel nut generally consists of betel leaf, areca nut, lime (wet/raw or dry), gambier, and tobacco. Common ingredients used in kinang are gambier, whiting, betel leaf and betel nut [3].
Betel leaf contains essential oils as much as 4\% (hydroxy cavikol, kavikol, cavibetol, estragol, eugenol, methyl eugenol, carvacrol, terpenes, and sesquiterpenes), tannins, diastae, sugar, and starch. The content of essential oils can kill germs (bacteriocides), and fungi [4]. Gambir is a product of the gambier plant (Uncaria gambir, Roxb) containing functional compounds that are included in the group of polyphenol compounds. The main components of gambier are catechins (catechin acids or catechu acids) and tannic catechins (catechins anhydrid) which have benefits as antioxidants and as inhibitors of the growth of Streptococcus mutans bacteria [5]. Lime contains calcium because it has the formula $\mathrm{CaCO} 3$. In general, calcium is a mineral that is very important for humans, especially as bone-forming [3]. Areca nut is a source of polymerized flavonoids and leucocyanidins, as well as small amounts of catechin, leucopelargonidin, and leucocyanidin. Flavonoids have activity as an antiseptic and alkaloids have the ability as an antibacterial. Chewing areca nuts and betel leaves can reduce the risk of oral cancer and buccal fibrosis [6].

The constituents of kinang, such as betel leaf, areca nut, gambier, and lime, contain active compounds that need to be further processed to optimize the content of these active compounds. Besides, the continued 
process can increase the added value of the kinang and be able to deliver the active compound more optimally. One effort that can be done is to do the extraction process and convert it into a powder so that the active compound obtained will be more optimal and easier to apply.

Extraction is an important process in the purification of important substances from the plant matrix [7]. One method in the extraction process is maceration. The maceration method is the simplest and most effective method, namely by dissolving plant powders using solvents that can penetrate plant cells and dissolve active substances [8].

Sifting is an operating unit in which a mixture of various sizes of solid particles is separated into two or more small parts by passing it on the screen (sieve). Or in other words, sifting is a process of separating material based on the size of the wire hole contained in the sieve, material smaller than the mesh size/hole will enter, while the larger size will be retained on the surface of the sieve wire. Each fraction is more uniform in size than the original mixture. The screen is a surface consisting of many holes of the same size. The surface can be flat (horizontal or tilted), or it can also be cylindrical. Flat-shaped screens that have a small capacity are also called sieves. Screening or sifting, in general, is a separation of sizes based on the classes in the sorting tool. The experimental principle of the sifting process in food is based on the particle size of material which has a size smaller than the mesh diameter to escape and material that has a size larger than the mesh diameter will be retained on the surface of the sieve wire [9].

Separating the size with this sieve can produce a uniform size so that the resulting kinang extract powder can be more easily applied and can provide added value. Therefore, this study aims to obtain kinang extract powder of various sizes and compare the physical and chemical characteristics of the kinang extract powder obtained. This research was expected to provide technological innovations in making kinang extract powder and can create functional food products that can provide health benefits.

\section{MATERIALS AND METHODS Preparation of kinang extract powder}

Kinang extract was produced by extraction using the maceration method. The constituents of kinang used were betel leaves (8 g,) gambir (2.5 g), lime (2 g), and areca nut (3.5 g) [10]. The ingredients of kinang were mashed and weighed. All ingredients that had been weighed were then mixed and put into bottles. Then the ingredients were added with water as the solvent of 1:10. The mixture of ingredients and water were shaken and allowed to stand according to the time of extraction treatment at room temperature. The time of extraction treatment were 24 hours, 48 hours and 72 hours. After the maceration process was finished, the solution was separated using gauze. The kinang extract obtained was made into a powder by drying using a freeze dryer. The dried material was then reduced according to the sieve size treatment. The sieve size treatment consisted of 60 mesh, 80 mesh and 100 mesh.

\section{Design of experiment}

The experiment was analyzed using a factorial randomized block design. Two factors were investigated, namely maceration time and sieve size. The extraction time treatment consisted of three levels, namely 24 hours, 48 hours and 72 hours (respectively coded by $\mathrm{T} 1, \mathrm{~T} 2$, and $\mathrm{T} 3$ ). The sieve size treatment consisted of three levels, namely 60 mesh, 80 mesh and 100 mesh (respectively coded by M1, M2, and M3).

\section{The physical, chemical and microbiology analysis}

The following parameters were observed, including physical, chemical and microbial analysis. The physical analysis of kinang extract powder consisted of bulk density [13]. The chemical analysis of kinang extract powder consisted of antioxidant activity [11], total phenol content [12] and moisture content [11]. The antimicrobial analysis of kinang extract powder consisted of antibacterial activity [14].

\section{RESULTS}

The values of antioxidant activity, total phenol, moisture content, bulk density, antibacterial activity of kinang extract powder was shown in Table 1. Results of analysis of variance showed that that maceration time (T) had significant effects on antioxidant activity, total phenol, antibacterial activity, moisture content, and bulk density. The sieve size (M) significantly affected moisture content and bulk density. Moreover, interaction of the two factors had significant effects on antibacterial activity and bulk density.

\section{DISCUSSIONS}

Measurement of the antioxidant activity value of kinang extract powder in this study using the DPPH method (1,1-diphenyl-2-picrylhidrazyl). In the DPPH method, the parameter used is the IC50 value. The IC50 values of antioxidant activity were ranging from $168.29 \mathrm{ppm}$ to $254.18 \mathrm{ppm}$. The highest IC50 value was $254.18 \mathrm{ppm}$ which was the treatments of 24 hours extraction time and 60 mesh sieve size. The lowest IC50 value was $168.29 \mathrm{ppm}$ which was the treatments of 72 hours extraction time and 100 mesh sieve size. The result showed that the longer the extraction time, the lower the IC50 value. A low IC50 value indicated high antioxidant activity. This was due to the length of time the extraction affects the amount of extract that came out. The longer the extraction time, the more extracts will be obtained. Therefore, the more extracts that come out, the higher levels of antioxidants obtained [15]. 
Table-1: Antioxidant activity, total phenol content, moisture content, bulk density and antibacterial activity of kinang extract powder

\begin{tabular}{|l|l|l|l|l|l|}
\hline Treatment & \multicolumn{1}{|c|}{ Antioxidant Activity } & \multicolumn{1}{|c|}{ Total Phenol } & \multicolumn{1}{|c|}{ Moisture Content } & \multicolumn{1}{c|}{ Bulk Density } & \multicolumn{1}{c|}{ Antibacterial Activity } \\
\hline $\mathrm{T}_{1} \mathrm{M}_{1}$ & $254.18 \pm 17.55^{\mathrm{a}}$ & $5.06 \pm 0.04^{\mathrm{c}}$ & $3.21 \pm 0.06^{\mathrm{a}}$ & $0.70 \pm 0.05^{\mathrm{abc}}$ & $0.88 \pm 0.18^{\mathrm{ef}}$ \\
\hline $\mathrm{T}_{1} \mathrm{M}_{2}$ & $250.02 \pm 17.38^{\mathrm{a}}$ & $5.11 \pm 0.64^{\mathrm{c}}$ & $3.04 \pm 0.02^{\mathrm{ab}}$ & $0.67 \pm 0.04^{\mathrm{abc}}$ & $0.69 \pm 0.06^{\mathrm{fg}}$ \\
\hline $\mathrm{T}_{1} \mathrm{M}_{3}$ & $235.39 \pm 5.89^{\mathrm{ab}}$ & $5.18 \pm 0.28^{\mathrm{c}}$ & $2.72 \pm 0.22^{\mathrm{bcd}}$ & $0.66 \pm 0.02^{\mathrm{abc}}$ & $0.57 \pm 0.02^{\mathrm{g}}$ \\
\hline $\mathrm{T}_{2} \mathrm{M}_{1}$ & $203.34 \pm 5.72^{\mathrm{bc}}$ & $6.10 \pm 0.07^{\mathrm{c}}$ & $2.90 \pm 0.06^{\mathrm{abc}}$ & $0.71 \pm 0.01^{\mathrm{ab}}$ & $0.98 \pm 0.05^{\mathrm{de}}$ \\
\hline $\mathrm{T}_{2} \mathrm{M}_{2}$ & $189.87 \pm 15.51^{\mathrm{cd}}$ & $6.18 \pm 0.88^{\mathrm{bc}}$ & $2.79 \pm 0.08^{\mathrm{bcd}}$ & $0.64 \pm 0.04^{\mathrm{bc}}$ & $1.12 \pm 0.04^{\mathrm{de}}$ \\
\hline $\mathrm{T}_{2} \mathrm{M}_{3}$ & $182.08 \pm 10.83^{\mathrm{cd}}$ & $7.92 \pm 1.56^{\mathrm{cb}}$ & $2.51 \pm 0.10^{\mathrm{d}}$ & $0.63 \pm 0.09^{\mathrm{bc}}$ & $1.16 \pm 0.05^{\mathrm{cd}}$ \\
\hline $\mathrm{T}_{3} \mathrm{M}_{1}$ & $171.08 \pm 18.19^{\mathrm{cd}}$ & $9.06 \pm 0.25^{\mathrm{a}}$ & $2.71 \pm 0.14^{\mathrm{bcd}}$ & $0.76 \pm 0.03^{\mathrm{a}}$ & $1.39 \pm 0.14^{\mathrm{bc}}$ \\
\hline $\mathrm{T}_{3} \mathrm{M}_{2}$ & $170.44 \pm 10.90^{\mathrm{cd}}$ & $9.12 \pm 0.15^{\mathrm{a}}$ & $2.59 \pm 0.14^{\mathrm{cd}}$ & $0.74 \pm 0.01^{\mathrm{bc}}$ & $1.68 \pm 0.06^{\mathrm{a}}$ \\
\hline $\mathrm{T}_{3} \mathrm{M}_{3}$ & $168.29 \pm 9.77^{\mathrm{d}}$ & $9.23 \pm 0.10^{\mathrm{a}}$ & $1.98 \pm 0.10^{\mathrm{e}}$ & $0.61 \pm 0.02^{\mathrm{c}}$ & $1.54 \pm 0.08^{\mathrm{ab}}$ \\
\hline
\end{tabular}

Note: values followed by the different letter was significantly different. according to Tukey's at the probably level of $5 \%$

Calculation of antioxidant activity using the DPPH method had a level of antioxidant strength namely IC50 value $<50 \mathrm{ppm}$ antioxidants are very strong, IC50 values 50-100 ppm antioxidants are strong, IC50 values are $100-250 \mathrm{ppm}$ antioxidants are moderate and 250-500 ppm antioxidants are weak [16]. The antioxidant activity of kinang extract powder using the maceration extraction method was in the category of weak antioxidant activity.

Phenol compounds are compounds distributed in plant parts, with varying degrees in each plant part. The leaves in many plants store phenol compounds that are distributed. Phenol compounds in plants that are used as antioxidants can be used to prevent free radical reactions. Phenol is a chemical structure derived from benzene derived from aromatic compounds. Basic phenol compounds that are soluble in water are generally glycosides in sugar and are usually present in cell vacuoles.

The values of total phenol content were ranging from $5.06 \mathrm{mg} / \mathrm{l}$ to $9.23 \mathrm{mg} / \mathrm{l}$. The highest total phenol value was $9.23 \mathrm{mg} / \mathrm{l}$ which was the treatments of 72 hours extraction time and 100 mesh sieve size. The lowest total phenol value was $5.06 \mathrm{mg} / \mathrm{l}$ which was the treatments of 24 hours extraction time and 60 mesh sieve size. The results showed that the longer the extraction time, the higher the total phenol value. Total phenol can be increased due to the length of the extraction frequency so that it affects the ability of the solvent to attract dissolved compounds. The longer the extraction lasts, the more effective the process of extraction takes place. This is because the process of diffusion of solvents into natural materials is getting better. The stages of the polyphenol extraction component from natural materials consist of two stages, namely the initiation and diffusion stages. At the initiation stage, particles from natural materials will absorb the solvent so that the particle is bubbled while the diffusion stage is characterized by the diffusion of the solvent to the deeper parts resulting in the polyphenol component being extracted [17].

In general, phenolic compounds (simple phenols or polyphenols) are highly correlated with the antioxidant activity possessed by a plant extract which is polyphenols, namely flavonoids, anthocyanins, and tannins, whereas for simple phenols such as phenolic acids. Hydrogen phenol can capture the free radicals that cause a majority of phenolic compounds that have antioxidant activity. The hydroxyl group can function as a contributor to a hydrogen atom when it reacts with radical compounds through an electron transfer mechanism so that the oxidation process is inhibited [18]. Therefore, in this study, the result of total phenol had correlated with the result of antioxidant activity.

Antibacterial substances are biological or chemical compounds that can inhibit bacterial growth and activity. Antibacterial activity was seen based on the diameter of the clear zone. The clear zone diameter values were ranging from $0.57 \mathrm{~mm}$ to $1.54 \mathrm{~mm}$. The result showed that the longer the extraction time, the higher the value of the clear zone $(\mathrm{mm})$. The high value of the clear zone indicates high antibacterial activity. This shows that the longer the extraction process, the antibacterial activity is also high. This is due to the longer the extraction process, the more extracts obtained including the phenol component. Phenol has antibacterial activity. Phenols cause damage to the permeability of bacterial cell walls, microsomes, and lysosomes caused by interactions between phenols and bacterial DNA. The lipophilic nature of phenol causes this compound to damage bacterial cell membranes. The more extracts produced are thought to increase the penetration of antibacterial compounds into the inside of microbial cells which will damage the cell's metabolic system and can result in cell death.

The inhibition zone formed $\geq 20 \mathrm{~mm}$ was considered to have very strong inhibitory activity, 10-20 $\mathrm{mm}$ was declared to have strong inhibitory activity, 5$10 \mathrm{~mm}$ was stated to have moderate inhibitory activity and $\leq 5 \mathrm{~mm}$ was stated to have weak inhibitory activity [19]. The inhibitory activity criteria of the kinang extract powder in this study were considered to have weak inhibitory activity because the inhibitory zone produced was $\leq 5 \mathrm{~mm}$. The cause of inhibitory activity in this study was weak due to the low value of total phenols. As previously explained that phenol can damage bacterial cell membranes. The low inhibitory activity of bacteria is influenced by the total phenol content of the kinang extract powder because phenol has antibacterial activity. Therefore, the inhibitory activity in this study is included in the weak category. 
The values of moisture content were ranging from $1.98 \%$ to $3.21 \%$. The lowest moisture content value was $1.98 \%$ which was the treatments of 72 hours extraction time and 100 mesh sieve size. The highest moisture content value was $3.21 \%$ which was the treatments of 24 hours extraction time and 60 mesh sieve size. The result showed that the longer the extraction time, the lower the moisture content value. The duration of extraction causes the moisture content in the material to evaporate [20]. Water is a material that can disperse a compound in the material. Moisture content can also affect physical properties (hardness or dryness) and physicochemical properties, chemical changes (enzymatic changes, enzymatic browning and microbiological damage) [21].

The values of bulk density were ranging from $0.61 \mathrm{~g} / \mathrm{ml}$ to $0.76 \mathrm{~g} / \mathrm{ml}$. The lowest bulk density value was $0.61 \mathrm{~g} / \mathrm{ml}$ which was the treatments of 72 hours extraction time and 100 mesh sieve size. The highest moisture content value was $0.76 \mathrm{~g} / \mathrm{ml}$ which was the treatments of 72 hours extraction time and 60 mesh sieve size. The result showed that the smaller the sieve size, the greater the bulk density value. This showed that the larger the particle size, the higher the bulk density value it has. The higher density of cages indicates the product is more dense or concise. Bulk density is influenced by several factors namely particle size, material properties, material composition and may also be affected by the degradation of the molecules in the material as a result of processing. So, the increase in bulk density may be due to the degradation of starch molecules, proteins, fats, and others when given initial cooking treatment so that the molecules occupy a narrower space.

\section{CONCLUSIONS}

The level of antioxidant activity and total phenol in this study was in the weak category. The treatment of extraction time had significant effects on antioxidant activity, total phenol, antibacterial activity, moisture content, and bulk density. The treatment of sieve size significantly affected moisture content and bulk density. The interaction of the two factors had significant effects on antibacterial activity and bulk density.

\section{ACKNOWLEDGMENTS}

This research was supported by research and publication through Hibah Profesi Grant of LPPM Sriwijaya University. We thank our colleagues from Sriwijaya University, South Sumatera, Indonesia who had contributed for insight and expertise that greatly supported the research.

\section{REFERENCES}

1. Samura JAP. Effect of Betel Eating Culture on Periodontal Health Status in Karo Tribe Communities in Biru-Biru Village, Deli Serdang
Regency. Universitas Sumatera Utara. Theses. 2009.

2. Siagian KV. Status of Dental and Oral Hygiene of Papuan Palm Chewers in Manado. Dentofasial. 2012; 11(1):1-6.

3. Siamtuti WS, Renika A, Zulvika KW, Nanang A, Indra VH. Potential of Tannins in Nginang Herb as an Environmentally Friendly Vegetable Insecticide. Bioeksperimen, 2017; 3(2):83-93.

4. Maryani H, Lusi K. Medicinal Plants for Influenza. Tangerang: Agromedia Pustaka. 2004.

5. Pambayun R, Gardjito M, Sudarmadji S, Kuswanto KR. Sensitivity of Positive Gram Bacteria to Catechins Extracted from Gambir (Uncaria gambir Roxb). Agritech; 2008; 28(4): 175-179.

6. Chavan Y, Singhal RS. Ultrasound-assisted extraction (UAE) of bioactives from areca nut (Areca catechu L.) and optimization study using response surface methodology. Innovative Food Science and Emerging Technologies, 2013; 17.

7. Alara OR, Abdurahman NH, Olalere OA. Ethanolic extraction of flavonoids, phenolics and antioxidants from Vernonia amygdalina leaf using two-level factorial design. Journal of King Saud University - Science. 2017.

8. Izza N, Shinta RD, Angky WP, Dian RY, Maria YSD. Extraction of Phenol Kenikir (Cosmos caudatus) Compounds with Pulse Electric Field (PEF). Jurnal Teknologi Pertanian, 2016;17(2).

9. Fellows, P. J. 1990. Food Processing Technology Principles and Practice. Ellis Horwood Limited. New York.

10. Verawati E. Functional Marshmallow with the Addition of Chewing Betel Extract. Universitas Sriwijaya. South Sumatera. 2017; 28-48.

11. AOAC. Official Methods of Analysis. (17 edn). Association of Official Analytical Chemist. Benyamin Frangklin Station. Washington DC. 2005.

12. Septiana TA. Muchtadi D, Zakaria R. Antioxidant Activity of Dichloromethane Extract and Ginger Water (Zingiber officinale Roscoe) in Linoleic Acid. Jurnal Teknologi dan Industri Pangan; 2002; 13(2):105-110.

13. Muchtadi TR. Sugiyono dan Fitriyono A. 2010. Ilmu Pengetahuan Bahan Pangan. Food Science. Alfabeta, Bandung. 2010.

14. Hamilton-Miller JMT, Shah S. Activity of The Tea Component Epicatechin Gallate and Analogue Against Methicillin-Resistant Staphylococcus aureus. Journal of Antimicrobial Chemotherapy; 2000; 46: 847-863.

15. Margaretta S, Swita DH, Nani I, dan Herman H. Phenolic Pandanus Amaryllifolius Roxb Extraction Compound. as a Natural Antioxidant. Widya Teknik, 2011; 10(1):21-30.

16. Putri ASP, dan Hidajati N. Antioxidant Activity Test of Phenolic Compounds Methanol Extract 
from Nyiri Batu Bark (Xylocarpus moluccencis). Unesa Journal of Chemistry, 2015; 4(1):37-42.

17. Prayitno SA, Joni K, Erni SM. Characteristics (Total Flavonoids, Total Phenols, Antioxidant Activity) Extract of Red Betel Leaf Powder (Piper crocatum Ruiz \& Pav.). Foodscitech, 2018; 1(2):26-34

18. Mohamad R, Widyastuti N, Suradikusumah E, Darusman LK. Antioxidant Activity, Phenol and Total Flavonoid Levels of Six Indonesian Medicinal Plants. Trad Med Journal, 2012; 18:2934.
19. Lingga AR, Usman P, dan Evy R. Antibacterial Test of Kecombrang (Nicolaia speciosa horan) Stem Extract against Staphylococcus aureus and Escherichia coli. JOM Faperta, 2015; 2(2).

20. Yulianti D, Bambang S, Rini Y. Effect of Extraction Time and Concentration of Ethanol Solvent on Physical-Chemical Properties of Stevia Leaf Extract (Stevia rebaudiana bertoni M.) with Microwave Assisted Extraction (MAE) Method. Jurnal Bioproses Komoditas Tropis, 2014;2(1): $35-41$.

21. Winarno. Food and Nutrition Chemistry. PT. Gramedia Pustaka Utama. Jakarta. 2004. 